This item was submitted to Loughborough's Research Repository by the author.

Items in Figshare are protected by copyright, with all rights reserved, unless otherwise indicated.

\title{
A diagnosis of construction and demolition waste generation and recovery practice in the European Union
}

PLEASE CITE THE PUBLISHED VERSION

https://doi.org/10.1016/j.jclepro.2019.118400

PUBLISHER

Elsevier BV

VERSION

AM (Accepted Manuscript)

PUBLISHER STATEMENT

This paper was accepted for publication in the journal Journal of Cleaner Production and the definitive published version is available at https://doi.org/10.1016/j.jclepro.2019.118400

LICENCE

CC BY-NC-ND 4.0

\section{REPOSITORY RECORD}

Sáez, Paola Villoria, and Mohamed Osmani. 2019. "A Diagnosis of Construction and Demolition Waste Generation and Recovery Practice in the European Union”. figshare. https://hdl.handle.net/2134/9825446.v1. 
Villoria Sáez, P, Osmani, M (2019) A diagnosis of construction and demolition waste generation and recovery practice in the European Union, Journal of Cleaner Production (In Press, available online). DOI: 10.1016/j.jclepro.2019.118400.

\title{
A diagnosis of construction and demolition waste generation and recovery practice in the European Union
}

\author{
Paola Villoria Sáez'; Mohamed Osmani² \\ ${ }^{1}$ Universidad Politécnica de Madrid. Escuela Técnica Superior de Edificación. TEMA \\ Research Group. Avenida Juan de Herrera, 628040 Madrid, Spain \\ ${ }^{2}$ School of Architecture, Building and Civil Engineering, Loughborough University \\ LE11 3TU, United Kingdom.
}

\begin{abstract}
Construction and demolition activities in the European Union (EU) are responsible for generating 850 million tonnes of construction and demolition waste (CDW) per year. As a result, the Waste Framework Directive (WFD) set a recovery target to attain $70 \% \mathrm{CDW}$ recycling by 2020. CDW management in individual EU Member States (MS) has been widely explored by previous researchers, however little attention has been paid to investigate the association of CDW arising with national economic, social and technological factors across different countries. Hence, this paper set out to examine and compare CDW generation across EU MS in correlation with their respective national construction turnover, gross domestic product and capita. It also assesses policy framework and CDW recovery performance of each MS against the WFD recovery target. Statistical data reported by Eurostat were collected and further analysed. A critical assessment of Eurostat CDW data reliability was carried out. A novel approach was adopted by ranking MS in respect to the amount of CDW generated per "construction turnover, GDP and capita' (CDW-TGC). Results show that Austria, Germany, Netherlands, Belgium and France were found to be the highest CDW-TGC producers, whereas Croatia, Slovenia, Slovakia, Poland, Portugal and Spain were found to be the lowest. Further, most MS rely on 'waste management plans' rather than specific national CDW regulations. No correlation was found between landfill taxation and CDW landfilled or recovered. Eleven MS still need to improve their recovery performance to achieve the WFD target. Finally, four key CDW recovery challenges were identified: ineffective CDW regulations, incoherent data quality, undeveloped reverse logistics and a low market readiness for secondary materials.
\end{abstract}

Key words: construction and demolition waste, generation, recycling, Europe, waste management 


\section{INTRODUCTION}

Failure to consider the wider implications of economic development has led to a global environmental crisis driven partially by wasteful material resources and accelerated pace of construction and demolition waste (CDW) generation around the world. In 2014, construction and demolition (CD) activities generated 1.13 billion tonnes in China (Lu et al., 2017); in excess of 850 million tonnes of waste in the European Union (EU) (Eurostat, 2018); and over 530 million tonnes in United States (US) (Environmental Protection Agency, 2018). The construction sector in the EU is the highest producer of waste when compared with other economic sectors, accounting for $35 \%$ of the total waste generation. This equates to two and four times more than the total household waste produced in US and Europe respectively (Environmental Protection Agency, 2018; Eurostat, 2018). This situation triggered attempts to develop international, national, regional and local CDW prevention and minimization programs. In particular, the European Commission approved the Waste Framework Directive 2008/98/EC (WFD), providing a general framework of waste management requirements and setting definitions regarding waste for the 28 Member States (MS) of the EU (European Parliament, 2008). The WFD introduces a detailed clarification of the 'Waste Hierarchy', which makes prevention the top waste management priority, followed by ' preparation for reuse', 'recycling', and 'recovery', and 'landfill' being the least desirable option. It also requires that all MS ensure that their competent authorities establish one or more 'Waste Management Plans (WMPs)' covering their entire geographical territory. WMPs should review the current waste management situation (type, quantity and source of waste generated, including information on CDW) and document the measures that will be taken to improve waste management in line with the 'Waste Hierarchy' (Justice and Environment, 2012).

One of the objectives of the WFD is to provide a framework for moving towards a European recycling society with a high level of resource efficiency. In particular, the Directive prescribed EU MS to implement measures to recover a minimum of $70 \%$ (by weight) of non-hazardous CDW (excluding soils) by 2020 (European Parliament, 2008).

In order to achieve this recovery target, the European Commission is encouraging the uptake of the circular economy by boosting CDW recovery and management. The EU Action Plan for the Circular Economy (European Commission, 2015) establishes general measures to be implemented throughout the whole cycle: from design, production and consumption to waste management; and supporting the EU market for secondary raw 
materials. Equally, extensive research works have been conducted in relation to CDW management (CDWM) across Europe, Hong Kong, the US, Australia, Malaysia and China (Ding and Xiao, 2014; Gálvez-Martos et al., 2018; Menegaki and Damigos, 2018). These studies focussed predominantly on CDW quantification, source evaluation and waste minimisation strategies across the lifecycle of products, buildings and assets.

The practical management of CDW varies greatly across MS due to local variations, legislation, enforcement, construction and demolition practices, and recycling infrastructure; and influenced by several factors, such as Gross Domestic Product (GDP), and capita. The same influencing parameters were also associated with other waste streams, such as municipal solid waste (Brown, 2015; Younes et al., 2015) and e-waste (Awasthi et al., 2018). Additionally, national CDW recovery performances between EU MS differ significantly (from $10 \%$ to over $95 \%$ ). MS with the lowest performances can certainly improve by applying good practices implemented by those achieving the highest performances. Furthermore, national monitoring of CDW waste generation and recycling performances are different from country to country. Therefore, national analysis regarding CDW generation and recovery is an essential step in assessing MS progress with regards to their recovery targets. Despite CDW generation and management in individual countries/regions has been explored over the past decades, less attention has been paid to compare the results across different regions (Menegaki and Damigos, 2018; Tam and Lu, 2016). In general, the amount of generated CDW has been routinely considered as an indicator for comparing waste management performance in different countries/regions. Deloitte (2017) argued that there is a need to establish the correlation between a socioeconomic indicators (e.g. turnover) and the amount of produced waste for the surveyed companies.

Regarding the research studies dealing with CDW generation, Menegaki and Damigos (2018) provided insights into factors influencing CDW generation in 34 different regions worldwide, including: China, USA, Australia, Hong Kong and other European countries. Results from the study showed that higher CDW generation is proportional related to countries with higher GDP and population density, an important issue affecting CDW generation. However, the influence of other issues identified in the study towards CDW generation could also be analysed, such as the construction turnover.

Santos et al. (2017) study provided information on the amount of CDW generated per capita in six regions of Portugal. Results showed that the amount of CDW generated per 
capita in Portugal ranges from $206 \mathrm{~kg}_{\text {inhab }}^{-1}$ year $^{-1}$ in Lisbon to $711 \mathrm{~kg}^{\text {inhab-1 }}$ year $^{-1}$ in the Algarve. Similarly, Tam and Lu (2016) investigated the relationship between construction waste management practices and GDP in Australia, Europe, Hong Kong, and the United Kingdom. However, the lack of available data did not allow for a robust analysis between economic profiles and construction waste management practices. Finally, a more recent study compared CDW generation with the construction turnover in Europe (Deloitte, 2017). Results from this study show that EU-MS generating the lowest amount of CDW per construction turnover are Portugal, Slovenia and Croatia with a ratio below 50 tonnes/Million Euros turnover. By contrast, Germany, Netherlands and Hungary were the MS generating the highest ratio above 400 tonnes/Million Euros turnover.

Despite previous research attempts to analyse CDW generation in relation to GDP or population, a comprehensive comparison between different regions considering other factors, such as the CD activity, is absent from literature. Therefore, this paper sets out to: (1) compare CDW arising and recovery performance across EU MS by examining the association between CDW generation and construction turnover; GDP; and capita; (2) assess their recovery rates and performance against the EU $70 \% \mathrm{CDW}$ recovery target by 2020 .

\section{METHODS}

The adopted methodology of this research encompasses the following five stages (Figure 1): (1) CDW Data reliability; (2) analysis of CDW generation rates for each selected EU MS; (3) analysis of CDW recovery rates in each EU MS; (4) performance of each selected MS against the EU 70\% CDW recovery target by 2020; and (5) CDW policy framework 


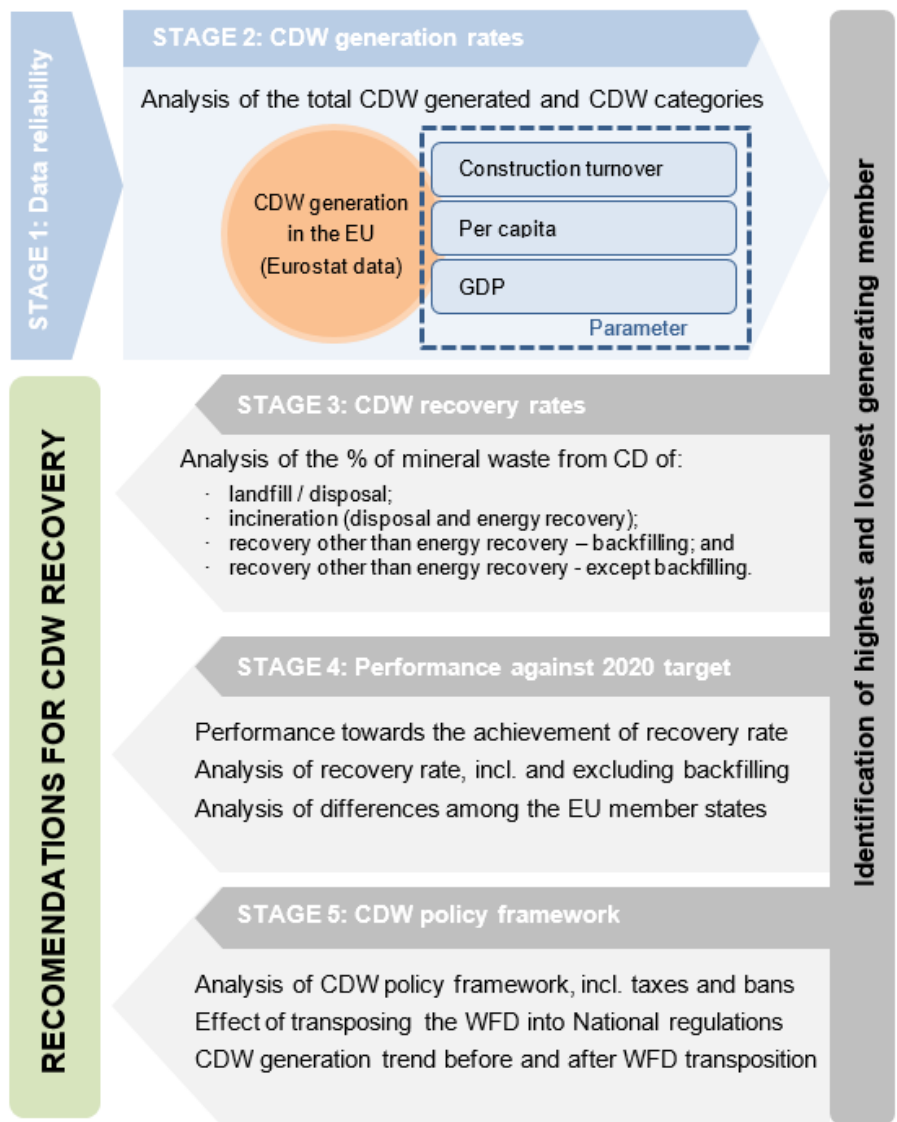

Figure 1. Methodology stages

\section{Stage 1: CDW Data reliability}

Data was collected from the Eurostat (2018), which is the main source data for Europe and has been commonly used by previous MS CDW studies, such as the European Commission in collaboration with Deloitte (2017) and the EU funded project "RE4" (RE4 project, 2017). For instance, the following authors cited information of CDW generation and recycling using Eurostat (2018) data: Fatta et al. (2003), Llatas (Llatas, 2011), Mália et al. (2013), Gangolells et al. (2014) and Silva et al. (2014). Moreover, other recent articles use Eurostat data to analyse the amount of CDW generation (Menegaki and Damigos, 2018; Santos et al., 2017; Tam and Lu, 2016).

The European Commission (Deloitte, 2017) carried out an assessment of the overall data quality of EU-28 MS using different methods, which culminated in grouping MS into 3 clusters in relation to their CDW data quality: 'good' (9 MS), 'modest' (10 MS) and 'poor' (9 MS) (Table 1).

Table 1. Construction and demolition waste data collection and quality for the 28 Member States (Deloitte, 2017; RE4 project, 2017) 


\begin{tabular}{|c|c|c|c|}
\hline $\begin{array}{l}\text { Member } \\
\text { State }\end{array}$ & Method to report CDW statistics & $\begin{array}{l}\text { Collection } \\
\text { method }\end{array}$ & $\begin{array}{l}\text { Overall } \\
\text { CDW } \\
\text { data } \\
\text { quality }\end{array}$ \\
\hline Austria & Follows Eurostat guidelines included in the Manual of waste statistics & ADS & Good \\
\hline $\begin{array}{l}\text { Czech } \\
\text { Republic }\end{array}$ & Follows Eurostat guidelines included in the Manual of waste statistics & S & Good \\
\hline Denmark Sta & $\begin{array}{l}\text { tatutory Order on Waste data system } \mathrm{N}^{\circ} 1306 / 2012 \text {. All waste } \\
\text { operators are obliged to give information of waste amounts, origin, } \\
\text { planned treatment and waste receiver. The waste is classified } \\
\text { according to the List of Waste codes. }\end{array}$ & ADS & Good \\
\hline Germany Da & $\begin{array}{l}\text { ata are reported by the treatment plants directly to the individual } \\
\text { statistical offices of the Federal States, which then provide the data } \\
\text { to the Federal Statistical Office }\end{array}$ & ADS & Good \\
\hline Netherlands & Follows Eurostat guidelines included in the Manual of waste statistics & ADS & Good \\
\hline Poland & Follows Eurostat guidelines included in the Manual of waste statistics & ADS & Good \\
\hline Portugal & $\begin{array}{l}\text { Statistics Portugal reports to Eurostat data regarding CDW } \\
\text { management according to the respective guidelines. The sample size } \\
\text { and selection is made at the business level (enterprise) not local } \\
\text { units. }\end{array}$ & S & Good \\
\hline Slovakia & $\begin{array}{l}\text { he generation and management of the waste data is done by the } \\
\text { regional waste information system RISO. The data collected from the } \\
\text { RISO reports is sent by the waste producers according to a limit on } \\
\text { the obligation to report data. }\end{array}$ & S; ADS & Good \\
\hline Slovenia CDI & $\begin{array}{l}\text { W data is gathered based on the National Statistics Act, the } \\
\text { Annual Programme of Statistical Surveys and the Decree on waste. }\end{array}$ & S; ADS & Good \\
\hline Belgium & $\begin{array}{l}\text { The data collection is different in each region: Flemish, Brussels, } \\
\text { Walloon. Data is gathered by collecting, sorting and treating facilities } \\
\text { and by producers of waste, who send their waste to another region. } \\
\text { This register uses list of waste codes. Some data are missing or } \\
\text { there is a problem of double counting. For instance, in the Flemish } \\
\text { region only enterprises have to report data and are taken into } \\
\text { account for the data collection. }\end{array}$ & $S$ & Modest \\
\hline Croatia & Follows Eurostat guidelines included in the Manual of waste statistics & ADS & Modest \\
\hline Estonia & Follows Eurostat guidelines included in the Manual of waste statistics & ADS & Modest \\
\hline France & $\begin{array}{l}\text { Uses a survey which reports waste amounts based on the latest } \\
\text { destination known by the producer, not the final one, as they are not } \\
\text { always aware of the final destination of their waste. }\end{array}$ & S & Modest \\
\hline Hungary & Follows Eurostat guidelines included in the Manual of waste statistics & S; ADS & Modest \\
\hline Italy & $\begin{array}{l}\text { Data are reported using the annually declarations done by the } \\
\text { entities (traders, businesses and Institutions) carrying out recovery } \\
\text { operations and waste disposal. }\end{array}$ & ADS & Modest \\
\hline Lithuania & Follows Eurostat guidelines included in the Manual of waste statistics & ADS & Modest \\
\hline Luxembourg & Follows Eurostat guidelines included in the Manual of waste statistics & S; ADS & Modest \\
\hline Spain & $\begin{array}{l}\text { Each Autonomous Region collect and report CDW statistics following } \\
\text { the list of waste codes. This data is then collected and compiled by } \\
\text { the Spanish Statistical Office. }\end{array}$ & S; ADS & Modest \\
\hline $\begin{array}{l}\text { United } \\
\text { Kingdom }\end{array}$ & $\begin{array}{l}\text { The CDW recovery rates given were submitted to Eurostat. However, } \\
\text { the estimation methodology was not able to use accurately identify } \\
\text { specific European Waste Classification for Statistics (EWC-STAT) } \\
\text { codes in generation and treatment of CDW. However, the } \\
\text { methodology used for calculating data is not identical across all UK } \\
\text { countries. Although absolute values of CDW are subject to a } \\
\text { relatively high level of uncertainty, sensitivity analysis suggests no } \\
\text { significant impact on the final recovery rates. }\end{array}$ & S; ADS & Modest \\
\hline Bulgaria & Follows Eurostat guidelines included in the Manual of waste statistics & S; ADS & Poor \\
\hline Cyprus & Follows Eurostat guidelines included in the Manual of waste statistics & S; ADS & Poor \\
\hline Finland & $\begin{array}{l}\text { Follows Eurostat guidelines, when reporting is under EWC-Stat } \\
\text { regulation requirements. }\end{array}$ & $\mathrm{S} ; \mathrm{ADS}$ & Poor \\
\hline Greece & Follows Eurostat guidelines included in the Manual of waste statistics & S; ADS & Poor \\
\hline
\end{tabular}




\begin{tabular}{|c|c|c|c|}
\hline $\begin{array}{l}\text { Member } \\
\text { State }\end{array}$ & Method to report CDW statistics & $\begin{array}{c}\text { Collection } \\
\text { method }\end{array}$ & $\begin{array}{l}\text { Overall } \\
\text { CDW } \\
\text { data } \\
\text { quality }\end{array}$ \\
\hline Ireland & Follows Eurostat guidelines included in the Manual of waste statistics & S; ADS & Poor \\
\hline Latvia & Follows Eurostat guidelines included in the Manual of waste statistics & ADS & Poor \\
\hline Malta & $\begin{array}{l}\text { Several methodological changes to improve the lack of private pre- } \\
\text { treatment facilities data. All data for } 2014 \text { is to be considered as } \\
\text { provisional. }\end{array}$ & ADS & Poor \\
\hline Romania & $\begin{array}{l}\text { Most of the times, CDW is mixed with the municipal waste and no } \\
\text { separate collection containers are provided for CDW and a large } \\
\text { number of business operators generating CDW, do not report it. Also, } \\
\text { the local authorities are not involved at all in collecting the data. }\end{array}$ & S & Poor \\
\hline Sweden & $\begin{array}{l}\text { The methodology follows the Swedish Environmental Protection } \\
\text { Agency guidelines, but the data collection underwent change due to } \\
\text { the uncertainties in the method. No decision has been made yet. } \\
\text { Compared to other sectors, the uncertainties in the current method } \\
\text { are rather high, and potential methodologies have been assessed. }\end{array}$ & S; ADS & Poor \\
\hline
\end{tabular}

Note:

S: Survey

ADS: Administrative data sources

Therefore, the data collected and further analysed in this study covers 19 MS (out of the 28) that deemed having supplied 'good' (nine MS) and 'modest' (10 MS) CDW quality data. On the other hand, nine MS: Malta, Finland, Bulgaria, Latvia, Romania, Greece, Cyprus, Ireland, and Sweden were removed from the study due to their poor level of data quality (Deloitte, 2017). That said, MS data on CDW was reported in different ways and using different methodologies by various national bodies to provide information to report against EU targets.

Furthermore, Eurostat codifies the waste streams using the European Waste Catalogue Classification code (EWC-STAT) since the Regulation (EC) 2150/2002 on waste statistics requires MS to report statistical data on waste generation using EWCSTAT codes (European Commission, 2010; European Parliament, 2002). Therefore, EWC-STAT code system was used in this study.

Stage 2: Analysis of CDW generation rates for each selected EU MS. This stage assesses the amount of CDW generated by each selected MS, considering not only the overall amount generated but also the different CDW streams. The amount of CDW generated reflects the overall CDW generation across different MS, which is inevitably influenced by the country's characteristics, such as economy, population or construction activity (Tam and Lu, 2016). Therefore, in order to compare the amount of CDW generated among different MS, CDW generation was analysed in relation to three parameters: construction turnover, GDP and per capita. The three analysed 
parameters are denoted as "TGC" and their associated values were taken from Eurostat database (Eurostat, 2018)

MS were ranked in terms of CDW generation severity regarding their CDW per TGC ratio. MS above the EU average were identified as the highest CDW generating MS and those situated within the last third of the MS list were identified as lowest CDW generating MS.

Stage 3: Analysis of CDW recovery rates in each EU MS: Eurostat provides statistics on waste management per waste category, without specifying the activity or industry. Therefore, CDWM data is only based on the waste category "construction and demolition (CD) mineral waste" instead of reporting the total waste generated in the construction sector. The percentage of mineral waste from $C D$ for each of the following management options were obtained for each MS from 2010-2014:

- landfill / disposal;

- incineration (disposal and energy recovery);

- recovery other than energy recovery - backfilling; and

- recovery other than energy recovery - except backfilling.

According to the WFD, "recovery" is defined as the waste serving a useful purpose by replacing other materials which would otherwise have been used to fulfil a particular function, or waste being prepared to fulfil that function, in the plant or in the wider economy (European Parliament, 2008). According to the guidance published by the European Commission, backfilling can be defined as the operations which involve reclamation purposes in excavated areas or engineering purposes in landscaping, however it has to substitute other materials that are not waste (European Commission, 2016).

Stage 4: Performance of each selected MS against the EU 70\% CDW recovery target by 2020: The WFD includes a specific CDW recovery target: "by 2020, the preparing for re-use, recycling and other material recovery, including backfilling operations using waste to substitute other materials, of non-hazardous CDW excluding naturally occurring material defined in category 170504 in the list of waste shall be increased to a minimum of $70 \%$ by weight" (European Parliament, 2008). Accordingly, the performance of each MS towards the achievement of this target is explored in this research. For this, Eurostat waste statistics (2018) regarding waste generation in CD activities gives information on the $\mathrm{kg}$ of construction, demolition and excavation waste 
(CDEW) per capita for each MS since 2004 with an interval of two years from 2004 to 2014. The total amount of construction, demolition and excavation waste statistics are available since 2004, while CDW data has only been available from 2010 to 2014 as the amount of soil and dredging spoil generated is only specified for those years. Therefore, in order to consider a broader period of time, data from 2004 to 2014 was used in this research despite the inclusion of excavated soils and dredging spoil.

Moreover, the definition of the CDW recovery target in the WFD enables MS to include the volumes used for backfilling in the calculation of their national CDW recovery target. However, the WFD also requires that MS "shall take measures to promote high quality recycling", which seems rather contradictory. Furthermore, as the WFD does not provide a definition for backfilling, there is relative confusion among MS concerning the term backfilling and its application as a recovery or a disposal operation (Deloitte, 2016). As such, the recovery rate including and excluding backfilling is examined and discussed for each selected MS. Eurostat requests MS to report their recovery rate statistics for CDW and associated management options. For this research, statistics covering the management carried out for mineral CDW were used to assess the percentage of backfilling for each country, because the recovery rates provided directly to Eurostat do not give information regarding backfilling.

Stage 5: CDW policy framework: the CDW policy framework was analysed for MS which were identified as the highest or lowest CDW generators in relation to the three TGC parameters in Stage 2. This was supplemented by a literature review to identify the CDW policy framework in each selected MS. Further, the effect of trasposing the WFD into MS national regulations was explored and assessed by clustering MS into two catergories; high and low CDW producers. This was carried out by collecting the weight in $\mathrm{kg}$ of construction, demolition and excavation waste per capita for each MS from 2004 to 2014, as well as the year in which the WFD was transposed or a specific CDW regulation was implemented. Finally, the trend before and after the WFD transposition is analyzed for each selected MS.

\section{RESULTS}

\subsection{Construction and demolition waste generation rates}

The CD sector in EU-28 generated around 858 Million tonnes in 2014 of construction, demolition and excavation waste, including 522 Million tonnes of soil and dredging spoil 
(Eurostat, 2018). Thus, 336 Million tonnes of CDW (excluding excavations) were generated in the EU in 2014. If excavated soils and dredging spoils are not considered, the different EWC-STAT categories generated in each EU-28 MS in 2014 were mineral wastes from CD activities, which encompass: concrete, bricks and gypsum waste, insulation materials, mixed construction wastes containing glass, plastics and wood, and hydrocarbonised road-surfacing material waste (Figure 2).

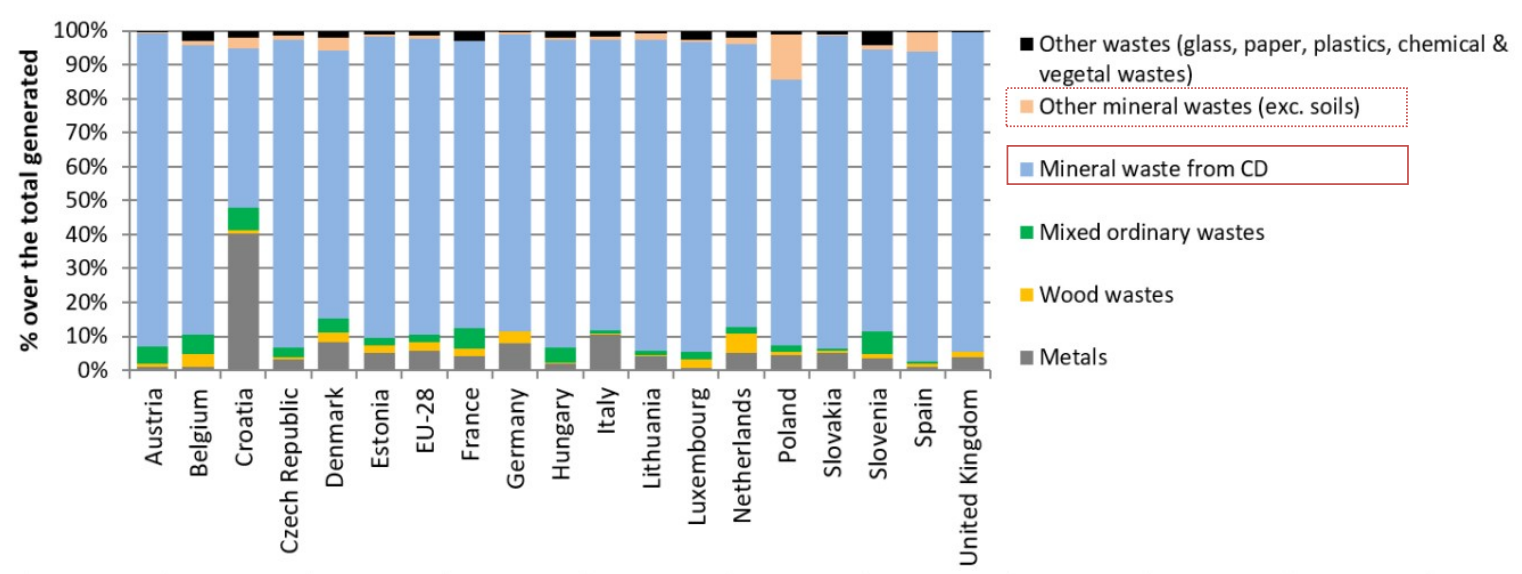

Figure 2. Percentage of each waste stream generated in each MS in 2014 (Eurostat, 2018).

In addition, it is critical to evaluate the amount and streams of CDW generated in the different CD activities. However, Eurostat (2018) waste statistics do not offer separate data for excavation, construction, refurbishment and demolition waste generation nor for associated types of project such as public works, buildings and civil structures. Therefore, it was not possible to obtain detailed aggregated data on CDW generation with respect to the types of $C D$ activities.

Table 2 shows the amount of CDW reported by EU-28 and for each analysed MS (19-MS) to Eurostat for the year 2014 (Eurostat, 2018), which expectedly shows that larger countries in terms of population generate greater amounts of CDW. For this reason, the amount of waste generated cannot be considered as a single parameter to quantify the waste generation rate. Other factors such as construction turnover, GDP and capita (TGC) of each MS need to be also considered as they influence the amount of waste generated in each country. As such, Table 2 also includes data for the three analysed TGC parameters, as well as for the total amount of CDW generated in EU-28 MS in 2014.

Table 2. Amount of CDW, construction turnover, GDP and capita of each analysed MS and for the whole EU28 during 2014 (Eurostat, 2018) 


\begin{tabular}{|c|c|c|c|c|c|c|c|}
\hline \multirow{2}{*}{ MS } & \multirow{2}{*}{$\begin{array}{c}\text { CDW } \\
\text { (Mtonnes) }\end{array}$} & \multicolumn{3}{|c|}{ Parameters analysed (TGC) } & \multicolumn{3}{|c|}{$\begin{array}{c}\text { Tonnes of CDW per } \\
\text { parameter }\end{array}$} \\
\hline & & Construction turnover (M€) & GDP (PPS)a & Capita $\left(x 10^{6}\right)$ & $\begin{array}{l}\mathrm{t} / \mathrm{M} € \text { of } \\
\text { turnover }\end{array}$ & $\mathrm{t} / \mathrm{GDP}$ & $\begin{array}{l}\text { t/ per } \\
\text { capita }\end{array}$ \\
\hline EU-28 & 336.73 & 1577430.10 & 14043716.60 & 507.37 & 213.47 & 23.98 & 0.66 \\
\hline Austria & 9.77 & 43341.60 & 307338.40 & 8.51 & 225.40 & 31.79 & 1.15 \\
\hline Belgium & 15.97 & 62065.00 & 368199.60 & 11.20 & 257.34 & 43.38 & 1.43 \\
\hline Croatia & 0.35 & 5062.40 & 69001.80 & 4.25 & 69.66 & 5.11 & 0.08 \\
\hline Czech Republic & 2.45 & 25390.50 & 250064.60 & 10.40 & 96.64 & 9.81 & 0.24 \\
\hline Denmark & 4.20 & 28316.20 & 198482.30 & 5.62 & 148.48 & 21.18 & 0.75 \\
\hline Estonia & 0.36 & 3910.30 & 27561.00 & 1.32 & 91.72 & 13.01 & 0.27 \\
\hline France & 72.11 & 288852.70 & 1958925.30 & 66.08 & 249.65 & 36.81 & 1.09 \\
\hline Germany & 90.97 & 241201.40 & 2806272.00 & 80.70 & 377.17 & 32.42 & 1.13 \\
\hline Hungary & 2.13 & 13044.00 & 185781.90 & 9.88 & 163.64 & 11.49 & 0.22 \\
\hline Italy & 39.94 & 170611.60 & 1619948.10 & 61.15 & 234.09 & 24.65 & 0.65 \\
\hline Lithuania & 0.43 & 4920.40 & 60582.00 & 2.94 & 87.43 & 7.10 & 0.15 \\
\hline Luxembourg & 0.57 & 6887.90 & 41613.60 & 0.55 & 83.34 & 13.79 & 1.04 \\
\hline Netherlands & 23.78 & 79287.00 & 606916.80 & 17.08 & 299.96 & 39.19 & 1.39 \\
\hline Poland & 4.28 & 59925.20 & 717518.10 & 38.02 & 71.37 & 5.96 & 0.11 \\
\hline Portugal & 0.93 & 18134.40 & 219990.20 & 10.43 & 51.10 & 4.21 & 0.09 \\
\hline Slovakia & 0.35 & 8030.80 & 115674.10 & 5.40 & 43.19 & 3.00 & 0.06 \\
\hline Slovenia & 0.12 & 4787.60 & 47280.80 & 2.06 & 24.90 & 2.52 & 0.06 \\
\hline Spain & 5.65 & 98546.20 & 1149572.20 & 46.51 & 57.35 & 4.92 & 0.12 \\
\hline United Kingdom & 55.42 & 268299.10 & 1946764.10 & 64.11 & 206.55 & 28.47 & 0.86 \\
\hline
\end{tabular}

The following sections compare the amount of CDW generated and the TGC for each selected MS.

\section{a) CDW generation per construction turnover}

Ratios of CDW generation per construction turnover for each MS in 2014 are shown in Table 3. Germany and the Netherlands have the highest ratio of CDW generationconstruction turnover. Conversely, MS, such as Slovenia, Slovakia, Portugal and Spain, have the lowest CDW generation-- construction turnover ratio. Moreover, the amount of CDW generated per M€ of turnover for all EU-28 MS is around 213.47 tonnes per M€ of turnover in 2014. In particular, six MS surpassed the EU-28 average (Germany, Netherlands, Belgium, France, Italy and Austria). Germany, the Netherlands and Belgium produced significantly more, surpassing 250 tonnes/M€ of turnover, while Slovenia produced very small amounts not exceeding 20 tonnes/M€ of turnover.

\section{b) CDW generation per GDP}

Ratios of CDW generation per GDP in terms of purchasing power standards (PPS) for each MS in 2014 are shown in Table 3. The amount of CDW generated per GDP for the EU-28 is 23.98 tonnes per GDP for the year 2014. The data reveal that seven of the analysed MS (36.84\%): Austria, Belgium, France, Germany, Italy, the Netherlands and United Kingdom had a higher ratio than the average of the EU-28. By contrast, the 
majority of MS (63.16\%) had a lower CDW/GDP ratio than the EU-28 average, generating well below as for example Slovenia, Slovakia and Portugal.

\section{c) CDW generation per capita}

Ratios of CDW generation per capita for each MS in 2014 are shown in Table 3. The EU-28 CDW per capita ratio is around 0.66. Data reveals that eight MS (42.11\%), surpass the EU-28 average (Austria, Belgium, Denmark, France, Germany, Luxembourg, Netherlands and United Kingdom), while others (57.89\%) generate well below the EU-28 ratio, as for example Slovenia, Slovakia, Croatia and Portugal, which generate less than 0.1 tonne of CDW per capita.

Table 3 shows the MS ranking in terms CDW generation severity, taking the three parameters analysed into consideration; and highlighting the highest and lowest MS generating CDW-TGC.

Table 3. MS ranking with respect to the amount of CDW generated per parameter analysed (data from Table 2)

\begin{tabular}{clrllll}
\multicolumn{2}{c}{ CDW vs turnover } & \multicolumn{2}{c}{ CDW vs GDP } & \multicolumn{2}{c}{ CDW vs capita } \\
& MS & t/M $€$ & \multicolumn{1}{c}{ MS } & MS & t/capita \\
\hline $\mathbf{1}$ & Germany & $\mathbf{3 7 7 . 1 7}$ & Belgium & $\mathbf{4 3 . 3 8}$ & Belgium & $\mathbf{1 . 4 3}$ \\
$\mathbf{2}$ & Netherlands & $\mathbf{2 9 9 . 9 6}$ & Netherlands & $\mathbf{3 9 . 1 9}$ & Netherlands & $\mathbf{1 . 3 9}$ \\
$\mathbf{3}$ & Belgium & $\mathbf{2 5 7 . 3 4}$ & France & $\mathbf{3 6 . 8 1}$ & Austria & $\mathbf{1 . 1 5}$ \\
$\mathbf{4}$ & France & $\mathbf{2 4 9 . 6 5}$ & Germany & $\mathbf{3 2 . 4 2}$ & Germany & $\mathbf{1 . 1 3}$ \\
$\mathbf{5}$ & Italy & 234.09 & Austria & $\mathbf{3 1 . 7 9}$ & France & $\mathbf{1 . 0 9}$ \\
6 & Austria & $\mathbf{2 2 5 . 4 0}$ & United Kingdom & 28.47 & Luxembourg & 1.04 \\
$\mathbf{7}$ & EU-28 & 213.47 & Italy & 24.65 & United Kingdom & 0.86 \\
$\mathbf{8}$ & United Kingdom & 206.55 & EU-28 & 23.98 & Denmark & 0.75 \\
$\mathbf{9}$ & Hungary & 163.64 & Denmark & 21.18 & EU-28 & 0.66 \\
10 & Denmark & 148.48 & Luxembourg & 13.79 & Italy & 0.65 \\
11 & Czech Republic & 96.64 & Estonia & 13.01 & Estonia & 0.27 \\
12 & Estonia & 91.72 & Hungary & 11.49 & Czech Republic & 0.24 \\
13 & Lithuania & 87.43 & Czech Republic & 9.81 & Hungary & 0.22 \\
14 & Luxembourg & 83.34 & Lithuania & 7.10 & Lithuania & 0.15 \\
$\mathbf{1 5}$ & Poland & $\mathbf{7 1 . 3 7}$ & Poland & $\mathbf{5 . 9 6}$ & Spain & $\mathbf{0 . 1 2}$ \\
$\mathbf{1 6}$ & Croatia & $\mathbf{6 9 . 6 6}$ & Croatia & $\mathbf{5 . 1 1}$ & Poland & $\mathbf{0 . 1 1}$ \\
$\mathbf{1 7}$ & Spain & $\mathbf{5 7 . 3 5}$ & Spain & $\mathbf{4 . 9 2}$ & Portugal & $\mathbf{0 . 0 9}$ \\
$\mathbf{1 8}$ & Portugal & $\mathbf{5 1 . 1 0}$ & Portugal & $\mathbf{4 . 2 1}$ & Croatia & $\mathbf{0 . 0 8}$ \\
$\mathbf{1 9}$ & Slovakia & $\mathbf{4 3 . 1 9}$ & Slovakia & $\mathbf{3 . 0 0}$ & Slovakia & $\mathbf{0 . 0 6}$ \\
$\mathbf{2 0}$ & Slovenia & $\mathbf{2 4 . 9 0}$ & Slovenia & $\mathbf{2 . 5 2}$ & Slovenia & $\mathbf{0 . 0 6}$ \\
\hline
\end{tabular}

Notes:

- Highest values generating waste for each parameter--above EU average- were marked in dark grey.

- Lowest values generating waste for each parameter.-ranked above the last third of the MS list- were marked in light grey

- MS highlighted in bold are those identified as highest or lowest values for the three parameters analysed. 
From the results shown in Table 3, MS with the highest and lowest CDW generation respectively were identified, taking into account the overall performance in association with the three parameters analysed into consideration:

- MS with the highest CDW generation rates: Austria, Germany, Netherlands, Belgium, and France.

- MS with the lowest CDW generation rates: Croatia, Slovenia, Slovakia, Poland, Portugal and Spain.

\subsection{Construction and demolition waste recovery rates}

In the EU-28 the percentage of CDW that has been landfilled has decreased from $22 \%$ reported in 2010 to $12 \%$ in 2014 , mainly due to the initiatives and instruments (legislative, financial, technology, etc.) that have been launched to promote CDW recovery and recycling (Eurostat, 2018). Eurostat statistics regarding the management of mineral CDW carried out in EU from 2010 to 2014 reveal that the generated mineral CDW streams are largely recovered (around $80 \%$ ) and smaller amounts are actually incinerated (around $4 \%$ ). Figure 3 shows the different waste management options used for mineral CDW across MS in 2014 (Eurostat, 2018).

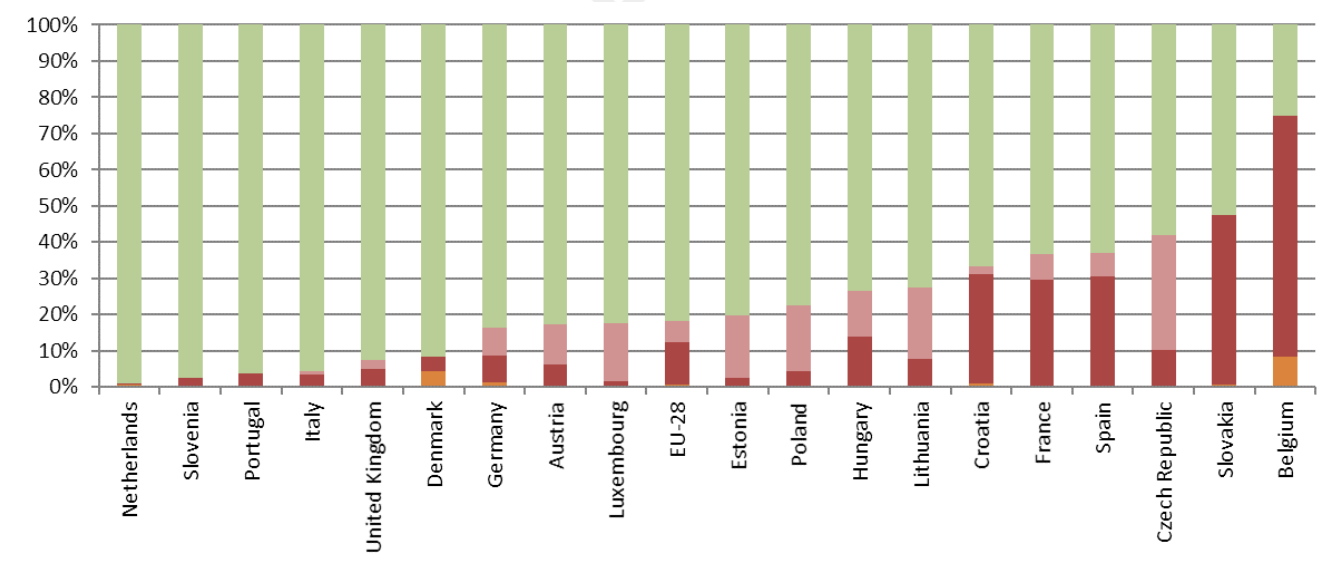

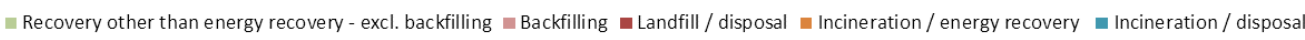

Figure 3. Management of mineral CDW across the analysed EU MS in 2014

The percentage of waste landfilled in 2014 varies from less than 1\% (Netherlands) to over $65 \%$ (Belgium). The amount of mineral CDW that is incinerated is minimal except in Denmark and Belgium, where there is a significant use of wood for construction activities. Similarly, the amount of backfilling appears to be small except for the Czech Republic, Estonia and Poland. 


\subsection{MS performance against EU 2020 construction and demolition waste recovery target}

Figure 4 shows the recovery rates of mineral waste from CD activities including backfilling from 2010 to 2014. Mineral CDW recovery rates were directly reported by all EU MS except for Germany and Luxembourg for the year 2014 (Eurostat, 2018).

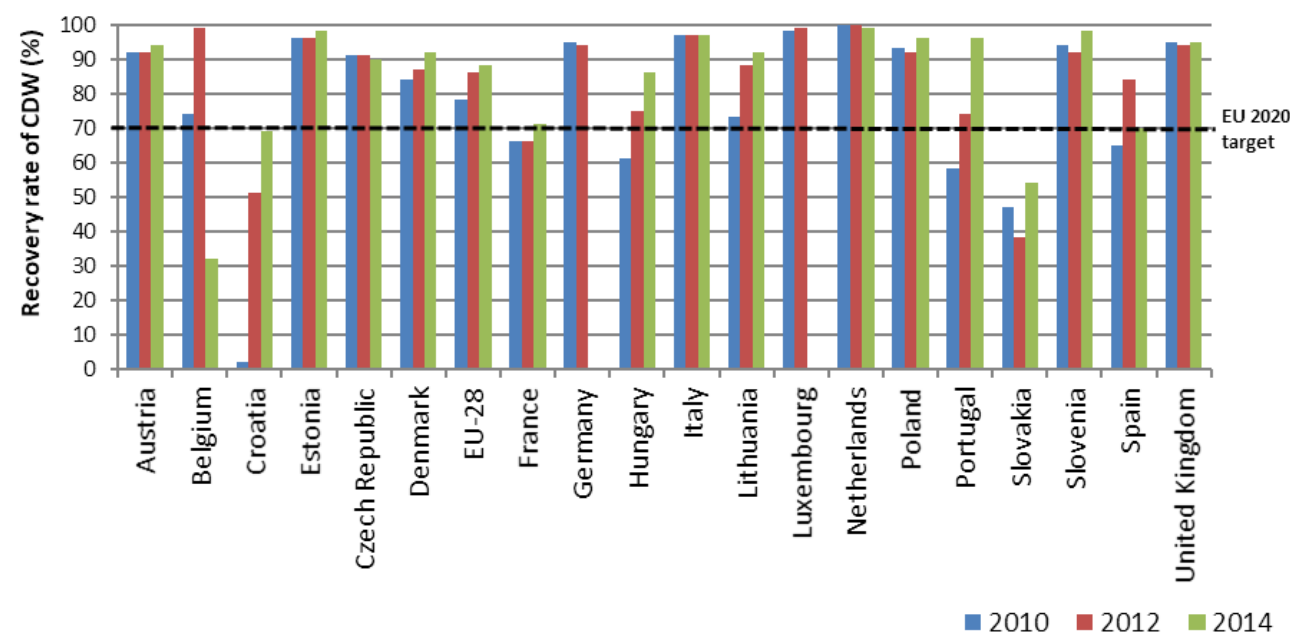

* Data was not available for Germany and Luxembourg for the year 2014.

Figure 4. Recovery rates of mineral CDW including backfilling in the analysed EU MS since 2010 to 2014

Results reveal that mineral CDW recovery rate in 2014 increased significantly in Croatia if compared with that of 2010, while it decreased in Belgium. In addition, 15 MS have already reached the $70 \%$ recovery target set in the Waste Framework Directive for the year 2020, whilst Belgium and Slovakia still need to take further measures to improve their rate, while two Germany and Luxembourg need to regularly provide their mineral CDW recovery statistics.

Moreover, the inclusion or exclusion of the amounts reported as backfilling influences the calculation of the recovery rate and results in great differences between some MS. Figure 5 shows the recovery rates of mineral CDW in the selected EU MS for 2014. Although Germany and Luxemburg did not state their recovery rates directly to Eurostat for the year 2014 (Figure 4), both countries reported the management of mineral CDW for 2014, which includes recovery. This reiterates the deficient quality of available data and the inconsistency and differences of data collection methods used by MS (Deloitte, 2016; Santos et al., 2017). Countries exhibiting higher differences of recovery rate depending on whether backfilling is included or excluded are: Croatia, France, Spain and the Czech 
Republic. Therefore, backfilling will be a determinant factor for some MS in order to meet the EU target for 2020.

Recovery performances between selected EU MS differ significantly from one country to another as a result of national variations in terms of legislation and enforcement, mineral CDW composition and recovery practices.

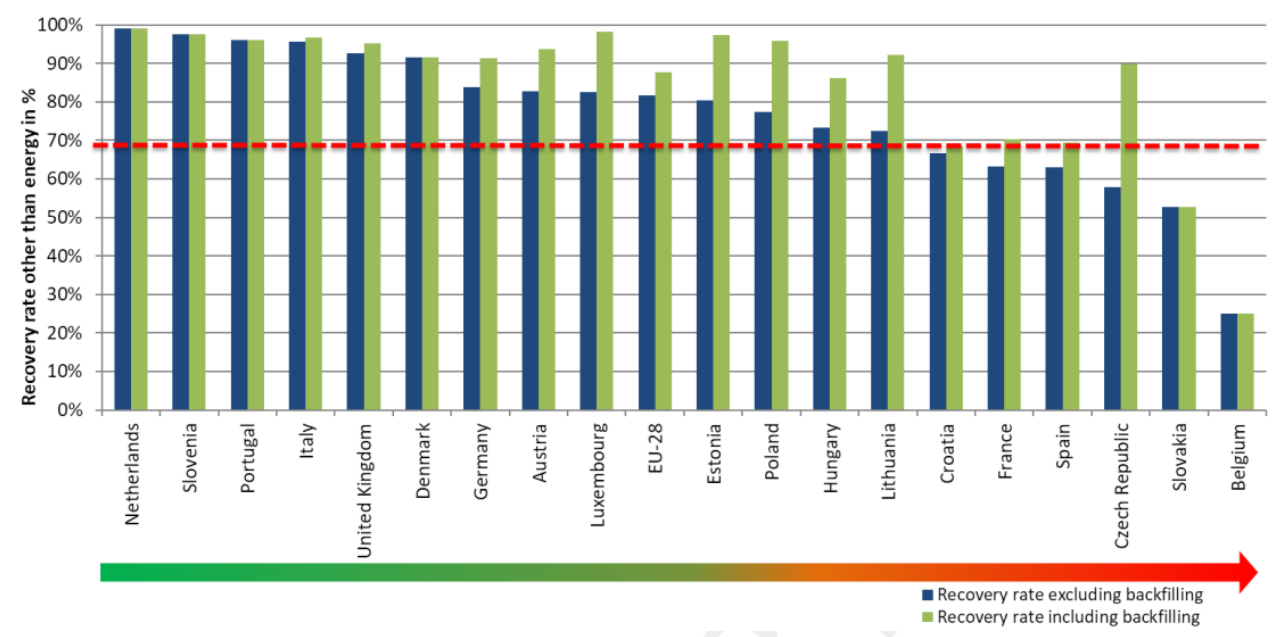

Figure 5. Recovery rates of mineral waste from CD including and excluding backfilling in EU MS in 2014

\subsection{Construction and demolition waste policy framework at MS level}

MS were required to transpose the WFD into their national policies before 2012. Table 4 shows the consequential national policies and regulations in the EU regarding CDWM, grouped MS into clusters based on the severity of their respective CDW generation.

Table 4. Transposition of the WFD into national regulations for high and low MS generating CDW (Deloitte, 2015a, 2016; EUR-Lex, 2017) 


\begin{tabular}{|c|c|c|c|}
\hline MS & & National Regulation & Specific for CDW* \\
\hline & Austria & Federal Act amending the Waste Management Act 2002 & - \\
\hline 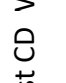 & Belgium & $\begin{array}{l}\text { Legislation of CDW varies from one region to another (three different waste } \\
\text { legislations). }\end{array}$ & - \\
\hline 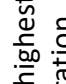 & 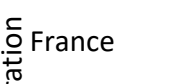 & $\begin{array}{l}\text { Law 2009-967 and Law 2010-788 make pre-audits compulsory on demolition } \\
\text { sites and CDW management plans. }\end{array}$ & $\checkmark$ \\
\hline 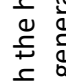 & 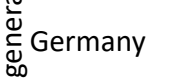 & $\begin{array}{l}\text { The Circular Economy Act is currently the main waste disposal regulation. The } \\
\text { legal framework for CDW recycling is specified in different state laws. }\end{array}$ & - \\
\hline 言 & & Act of 3 February 2011 amending the Environmental Management Act, the & \\
\hline$\sum^{n}$ & Netherlands & $\begin{array}{l}\text { Environmental Taxes Act and the Economic Offenses Act for the implementation } \\
\text { of WFD. }\end{array}$ & - \\
\hline & Croatia & The Act on Sustainable Waste Management (OG 94/13) & - \\
\hline 总 & Portugal & $\begin{array}{l}\text { Decree-Law } 46 / 2008 \text { establishes the legal framework for waste management } \\
\text { resulting from construction works, demolition of buildings or collapses. }\end{array}$ & $\checkmark$ \\
\hline 으 을 & ${ }_{\pi}^{\circ}$ Slovakia & Act no. $343 / 2012$ on Waste & - \\
\hline 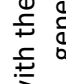 & 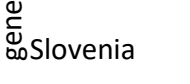 & $\begin{array}{l}\text { Decree on the management of waste arising from construction work of } 22 \text { April } \\
2008 .\end{array}$ & $\checkmark$ \\
\hline$\stackrel{3}{n}$ & Spain & National Law for CDW management - Royal Decree 105/2008 & $\checkmark$ \\
\hline & Poland & Act on Waste of 2012 & - \\
\hline
\end{tabular}

* MS with specific national regulation for CDW management

Despite the fact that MS shown in Table 4 have transposed the WFD into their national regulations, just four MS (France, Portugal, Slovenia and Spain) of those analyzed in Table 4 have developed specific regulations for CDWM, while other MS developed waste management plans or regulations pertaining to their respective local authorities. For instance, Flanders (Belgium) has implemented a plan of execution for CDW since 1995, whilst Germany started a voluntary commitment to halve the amount of CDW landfilled in 1996 (Deloitte, 2016; Monier et al., 2011). Among the MS with the highest CDW generation, France is the only EU country with a national regulation for CDW management; however this considers only demolition activities. It is interesting to note that three of the MS with lower CDW generation rates (Portugal, Slovenia and Spain) have a specific national regulation for CDWM.

Moreover, analysing the CDW generation trend before and after the WFD implementation year is essential to identify the influence of the WFD in the reduction of CDW generation. Indeed, Table 5 shows CDW generation data from Eurostat for each selected MS, which is classified and structured according to their WFD implementation year.

Table 5. construction, demolition and excavation waste generation (kg per capita) and the year of WFD transposition for high and low MS generating CDW as well as for the EU-28 MS 


\begin{tabular}{|c|c|c|c|c|c|c|c|c|c|}
\hline & & Year of WFD transposition & $\mathrm{CDE}$ & $E W^{a} g$ & neratic & $\mathrm{n}(\mathrm{kg} \mathrm{p}$ & per cap & ita) & $\%$ change since \\
\hline & MS & (baseline year) & 20042 & 20062 & 00820 & 10201 & 12201 & & $\begin{array}{c}\text { baseline year to } \\
2014\end{array}$ \\
\hline & France & 2009 & 3359 & 3552 & 3942 & 4022 & 3770 & 3447 & -14.30 \\
\hline 0 & Austria & 2010 & 3418 & 3788 & 3772 & 2502 & 3970 & 4714 & 88.41 \\
\hline $\bar{\omega} \frac{\bar{\sigma}}{\omega} \stackrel{\frac{\Phi}{\sigma}}{\sigma}$ & Netherlands & 2011 & 3048 & 3470 & 3581 & 4698 & 4725 & 5380 & 13.86 \\
\hline$\frac{0}{0} \frac{2}{0}$ & Belgium & 2012 & 1059 & 1241 & 1442 & 1667 & 1518 & 1521 & 0.20 \\
\hline 잎 임 & Germany & 2012 & 2322 & 2386 & 2402 & 2336 & 2456 & 2550 & 3.83 \\
\hline$>\mathscr{Q}$ & Portugal & 2008 & 250 & 343 & 129 & 168 & 88 & 145 & 12.40 \\
\hline 方苋 & Slovenia & 2008 & 455 & 496 & 681 & 737 & 260 & 395 & -42.00 \\
\hline 0 & Spain & 2008 & 1079 & 1066 & 978 & 815 & 559 & 439 & -55.11 \\
\hline 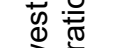 & Croatia & 2011 & 150 & 4 & 30 & 2 & 158 & 146 & -7.59 \\
\hline & Poland & 2012 & 44 & 371 & 182 & 547 & 404 & 447 & 10.64 \\
\hline & Slovakia & 2012 & 261 & 171 & 242 & 331 & 149 & 256 & 71.81 \\
\hline & EU-28 & 2008 & 1552 & 1681 & 1725 & 1707 & 1661 & 1692 & -1.91 \\
\hline
\end{tabular}

Note: The year of WFD or CDW national regulation implementation (baseline year) is highlighted in bold

${ }^{a}$ Construction, demolition and excavation waste

The average CDW generation for EU-28 has remained around $1669.67 \mathrm{~kg}$ per capita after six years of WFD implementation, showing a percentage change since 2004 lower than $2 \%$. This may be explained due to the delay of some countries in transposing the WFD into their national regulations. While CDW generation per capita decreased in five MS after the transposition of the WFD, this increased in seven MS - mainly in Slovakia (71.81\%) and Austria (88.41\%)-. This could be explained by the CD activity level of the country, as for example the increase in CD activities in Austria or their decrease in Slovakia in 2012 (Daniela et al., 2016). These differences on the CD activity of each MS were common during 2008-2015 due to the economic crisis affecting Europe (Namlis and Komilis, 2019). As such, other aspects influencing the amount of CDW generated, such as the economic activities of each MS, also need to be considered when assessing CDW generation.

In addition to the WFD, MS have implemented landfill taxes or bans to reduce the amount of CDW generated and to improve its management. Table 6 summarizes the landfill taxes of the highest and lowest CDW MS, which vary considerably in terms of both quantity and type of waste streams. 
Table 6. Landfill bans and taxes for high and low MS generating CDW (CEWEP, 2017; Deloitte, 2015b; Ettlinger and Bapasola, 2016; Fischer et al., 2012; Marinheiro and Russo, 2014)

\begin{tabular}{|c|c|c|c|c|c|}
\hline \multicolumn{2}{|c|}{ MS } & \multirow{2}{*}{ 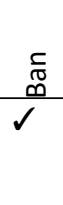 } & \multirow{2}{*}{$\frac{\stackrel{x}{\sigma}}{\stackrel{\Gamma}{d}}$} & \multirow{2}{*}{$\begin{array}{l}\text { Details } \\
\text { Tax exists since 1999. For MSW is around } 87 € / t \text { but depends on } \\
\text { composition of waste and standard of the landfill. } \\
\text { For construction or inert waste and soil excavation: } 9.20 € / \mathrm{t}\end{array}$} & \multirow{2}{*}{$\begin{array}{l}\text { Tax for CDW } \\
€ / \text { tonne } \\
9.20\end{array}$} \\
\hline & Austria & & & & \\
\hline 岁 & Belgium & $\checkmark$ & $\checkmark$ & $\begin{array}{l}\text { Brussels has no landfills. } \\
\text { Flanders has a landfill tax which ranges from } 56.05 € / \mathrm{t} \text { for non- } \\
\text { combustible waste to } 101.91 € / \mathrm{t} \text { for combustible waste } \\
\text { Wallonia ranges from } 62.16 € / \mathrm{t} \text { for non-combustible waste to } 113.01 \\
€ / \mathrm{t} \text { for general waste }\end{array}$ & $56.05-113.01$ \\
\hline 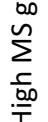 & France & $\checkmark$ & $\checkmark$ & $\begin{array}{l}\text { Vary from } 150 € / t \text { to } 15 € / t \text { depending on the standard of the landfill } \\
\text { and not on the nature of waste streams. The general landfill tax(2014): } \\
30 € / t \text { and (2015): } 40 € t\end{array}$ & 30.00 \\
\hline & Germany & $\checkmark$ & $x$ & No tax & - \\
\hline & Netherlands & $\checkmark$ & $\checkmark$ & $\begin{array}{l}\text { Introduced in 1995, repealed in } 2012 \text { and reintroduced in } 2015.13 .11 € \\
\text { per tonne in } 2017\end{array}$ & 13.11 \\
\hline & Croatia & $\checkmark$ & $x$ & $\begin{array}{l}\text { No tax. A fee is encouraged by the WMP for 2017-2022, but not applied } \\
\text { yet. }\end{array}$ & - \\
\hline & Poland & $\checkmark$ & $\checkmark$ & $\begin{array}{l}33 € / t \text { ( } 140 \mathrm{PLN}) \text { in } 2018 ; 40 € / \mathrm{t}(170 \mathrm{PLN}) \text { in } 2019 ; 40 € / \mathrm{t}(270 \mathrm{PLN}) \\
\text { from } 2020\end{array}$ & 33.00 \\
\hline & Portugal & $x$ & $\checkmark$ & Tax introduced in 2007. 4.27 €/tonne (CDW) in 2014 & 4.27 \\
\hline 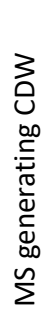 & Slovakia & $\checkmark$ & $\checkmark$ & $\begin{array}{l}\text { Tax introduced in } 2014 \text { and rates vary since } 2016 \text { depending on the } \\
\text { number of separated fractions: } \\
\text { MSW: } 9.96 € / t \text { (less than } 4 \text { separate fractions) to } 4.98 € / t \text { (in } 5 \\
\text { separate fractions) } \\
\text { Hazardous waste: } 33.19 € / t \\
\text { Inert waste: } 0.33 € / t \\
\text { Other waste } 6.64 € / t \\
\text { Biowaste } 13.28 € / t\end{array}$ & 0.33 \\
\hline 3 & Slovenia & $\checkmark$ & $\checkmark$ & $\begin{array}{l}\text { Tax introduced in } 2001 \text {. (still in application in 2017) } \\
\text { MSW/Non-hazardous waste: } 11 € / t \\
\text { Inert: } 2.2 € / t \\
\text { Hazardous: } 22 € / t\end{array}$ & 2.2 \\
\hline & Spain & $x$ & $\checkmark$ & $\begin{array}{l}\text { Landfill taxes vary in each region: } \\
\text { MSW: } 12-30 € / \mathrm{t} \text {. Will reach } 41.3 € / \mathrm{t} \text { in } 2019 \text {. } \\
\text { Industrial waste: } 2-35 € / \mathrm{t} \\
\text { CDW: } 0,5-4 € / \mathrm{t}\end{array}$ & $0,5-4$ \\
\hline
\end{tabular}

Landfill taxes have been implemented differently among MS, with some countries having regional disparities or variations for different materials. For instance, landfill bans were introduced for recyclables in the Netherlands; mixed CDW landfill in Belgium; and waste suitable for incineration in Denmark (CEWEP, 2017; Oosterhuis et al., 2009), which might explain its relatively high levels of CDW incineration (5\%).

According to the European Environment Agency study, 24 out of the 28 EU MS use landfill taxes as part of their waste management policies across all sectors (EEA, 2016). Landfill taxation coverage and rates vary among the different MS, ranging from $3 € /$ tonne in Lithuania to more than 100€/tonne in Belgium (CEWEP, 2017). The remaining four MS without landfill taxation are: Cyprus, Germany, Luxemburg and Malta. Moreover, Greece 
suspended its Landfill Tax in 2017, whereas Croatia is encouraging the implementation of a landfill tax in its WMP but has not applied it yet (CEWEP, 2017).

Significant differences in CDWM among the EU MS could be due to the following factors that differ from country to country: (i) construction and demolition waste management regulations; (ii) landfill taxes and bans; (iii) CDWM facilities; (iv) the costs of primary raw materials (PRM) and the existence of a market for secondary raw materials (SRM) for the EU construction industry. These factors are examined below.

- i) Construction and demolition waste management regulations: different regulations with regard to CDW also reveal important disparities between EU MS shown in Table 4. Poland, which has a high CDW recovery rate, do not have specific regulation regarding CDW; while Austria and the Netherlands rely mostly on soft steering frameworks, such as Waste Management Plans or regulations pertaining to local authorities.

- ii) Landfill taxes and bans: low recovery rates may be explained by low landfill taxes and bans or small penalties for waste disposal (Bartelings et al., 2005). Figure 6 show the relation between the landfill taxes and the percentage of recovered waste for high and low MS generating CDW. Germany and Croatia were not included in the analysis of data as they don't have landfill taxation. However, in order to broaden the scope of this research, Denmark and the United Kingdom were included because they surpass $90 \%$ of the CDW recovery and have a landfill tax.

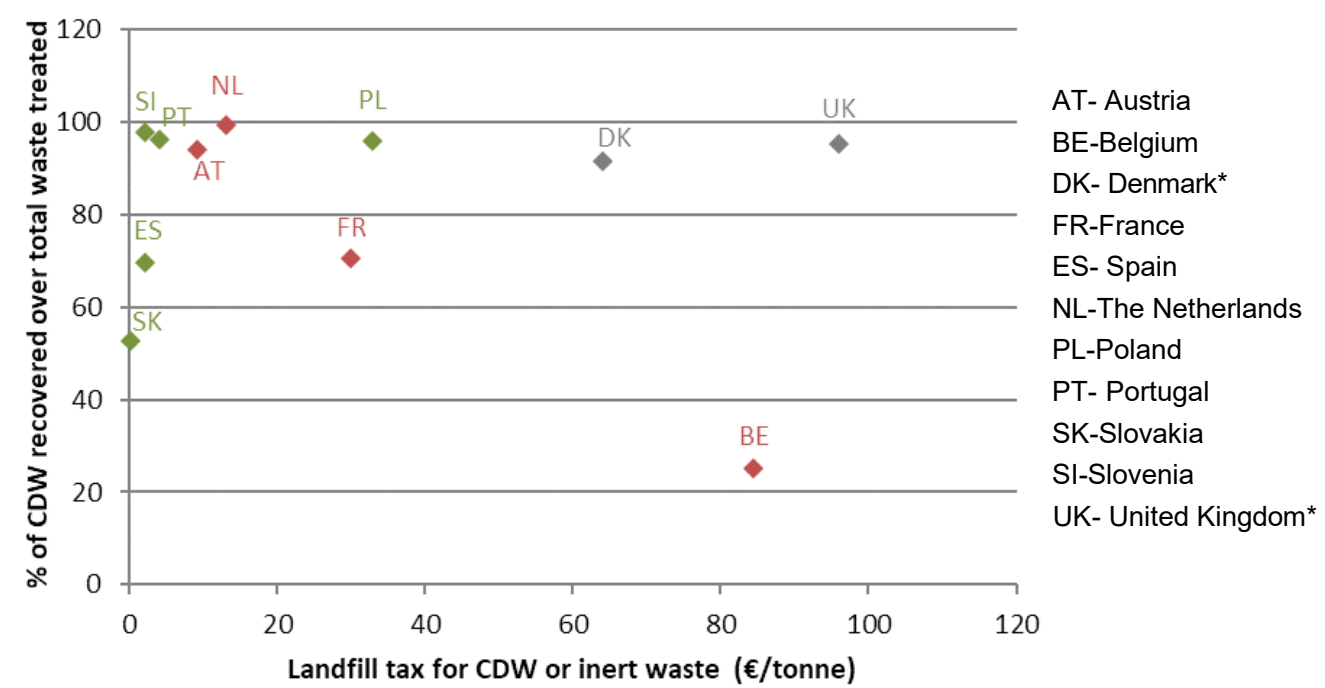

* Landfill taxes used for United Kingdom and Denmark were 84.4€ (96.24€) and DKK 475 (64€) respectively.

Figure 6. Relation between landfill tax and percentage of CDW recovered in 2014 
Results show no correlation between the Landfill Tax and the percentage of recovered $\mathrm{CDW}$, despite the fact that landfill taxes are often considered as a driver for CDW recovery and recycling (Bartelings et al., 2005; Calvo et al., 2014). For instance, Denmark and the United Kingdom have high disposal costs and high recovery rates; while Austria, the Netherlands, Slovenia and Portugal also have high recovery rates but have low disposal costs. It is interesting to note that countries such as Denmark and the United Kingdom have landfill taxes and good recovery rates; whilst Germany has a high level of CDW recovery without using landfill taxation. This can be explained by other factors which also affect the waste management carried out in each MS, such shortage of raw materials; availability of CDWM infrastructure, policy framework that promote recycling, and the awareness programmes.

No correlation between the percentage of CDW landfilled and landfill taxation was also found by previous research works. For instance, Menegaki \& Damigos (2018) study concluded that landfill taxes have been implemented in many countries, but using waste disposal fees is not a simple issue, since it may give rise to illegal waste dumping. Also, the European Commission report found no clear correlation between disposal costs and recovery rates, most probably due to the fact that many other factors may affect the waste route in each MS (Deloitte, 2017).

iii) CDW management (CDWM) facilities: At present, there is no database available containing all waste treatment facilities specifically for CDW in the EU. However, a first approach has been developed here analysing the amount of waste generated and the overall waste facilities in each MS provided by Eurostat. Figure 7 shows the amount of waste recovered and the number of waste facilities in each selected MS in 2014. 


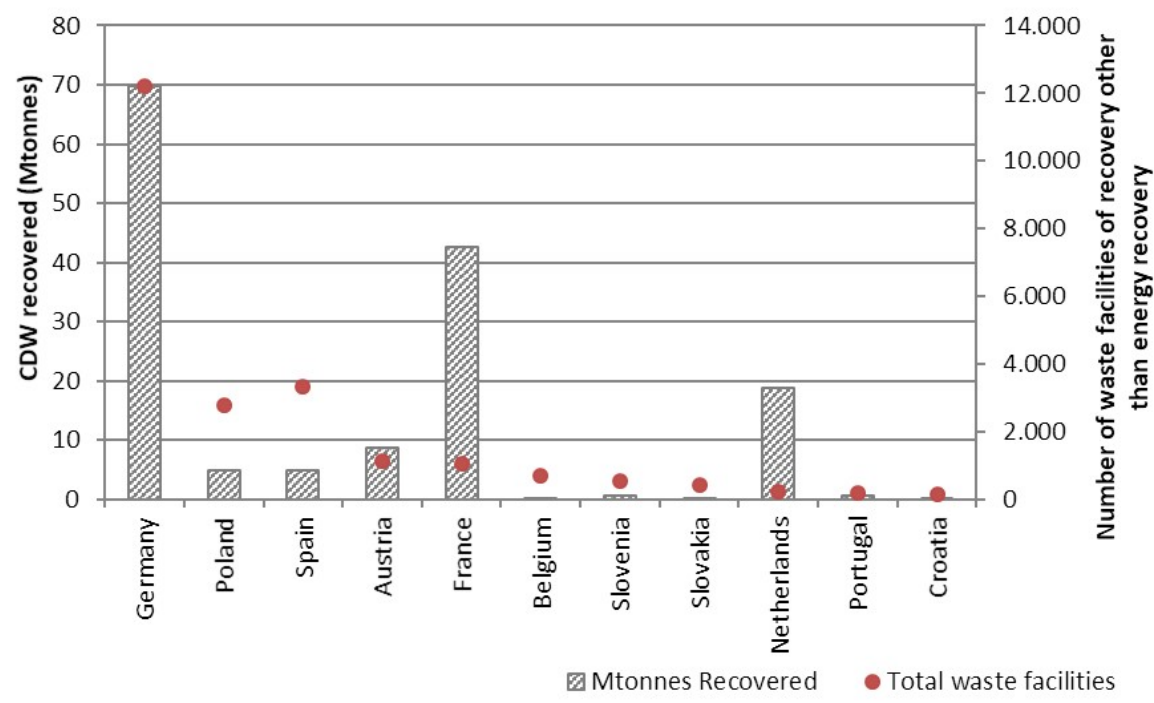

Figure 7. Amount of CDW recovered and number of waste facilities for each MS in 2014.

In general, countries with higher recovery quantities, such as the United Kingdom and Germany, have a dense network of CDWM facilities; whereas other countries such as Croatia and Slovakia have a smaller number or inadequate distribution of CDWM facilities (Deloitte, 2016).

iv) Cost of primary raw materials (PRM) and existence of a market for secondary raw materials (SRM) in the European construction industry: Having sufficient and available PRM -providing enough quality at a moderate cost- makes it difficult to develop SRM markets --as happens in Spain and Portugal-- especially if they do not implement other initiatives to promote the use of SRM (Vieira and Pereira, 2015).

In addition, another reason why SRM are not commonly implemented in some countries is due to the lack of construction actors' confidence in recycled construction materials (R2 Project, 2018; Tingley et al., 2017; Wahlström et al., 2019), despite the fact that SRM fulfil technical requirements and quality standards equivalent to the PRM (Oyedele et al., 2014; Taffese, 2018). Moreover, the nonexistence of an effective regulation framework for the use of recycled materials, as well as the lack of legal requirements which set the maximum/minimum waste content in construction materials also influence the SRM market.

\section{Conclusions}

This paper presents the first systematic multi-faceted analysis of EU MS CDW generation rates, recovery rates, policy framework, and their performance against WFD 70\% CDW 
preparing for re-use, recycling and recovery target by 2020. From the current situation of CDW generation and management in the EU, the following conclusions can be drawn:

- No correlation was found between the landfill taxation and the percentage of CDW landfilled or recovered of the highest and lowest CDW MS, as the landfill taxation vary considerably in terms of both quantity and type of waste streams.

- Europe as a whole has achieved the target of recovery for the year 2020, including backfilling. However, there are still eleven MS -out of the 19 analysed- which need to improve their recovery performance in order to achieve the EU target.

- Austria, Germany, Netherlands, Belgium and France were found to be the highest ranked in terms of CDW-TGC generation severity, and Croatia, Slovenia, Slovakia, Poland, Portugal and Spain the lowest. However, future research on CDW estimation should be developed considering a holistic approach via temporal spatial statistics and multi-criteria decision analysis (MCDA) that take into account criteria weightings; additional factors at national and regional levels, e.g. social and technological criteria as well as CDW end-markets, and future scenarios, e.g. impact of MS population and GDP growth on CDW generation.

- Among the analysed MS, only four (France, Portugal, Slovenia and Spain) have developed specific national regulations for CDW and most of the countries rely on Waste Management Plans or local regulations.

- From the current situation of CDW generation and management in Europe four key CDW recovery challenges face MS. These are: ineffective CDW regulations; poor data quality and harmonization; poor reverse logistics; and a low market readiness for secondary materials.

The results and recommendations of this research are relevant to the key EU construction stakeholders, including the EU Commission, MS and construction organisations. As such, urgent actions would be to address the significant gaps and concerns over the plausibility of CDW data. Special emphasis by the EU should be directed in defining common methods for accurately measure CDW generation and recovery performance rates across MS, as well as developing models to help estimate the amount of CDW generated considering multi-faced economic and social factors. Additionally, efforts should be made to set minimum quality specifications and standards to record the amount of CDW generated by each country and harmonize them across MS. Similarly, National authorities should focus in developing specific national CDW regulations, assuring greater policy integration and enforcement, and developing viable CDW recycling and recovery infrastructure network. The findings of this research add value to the EU monitoring of the 
progress of MS in relation to WFD 70\% CDW recovery target by 2020 through a novel cross-country CDW-TGC analytical lens.

\section{Acknowledgements}

This article is based on research activities of COST Action CA15115 Mining the European Anthroposphere (MINEA) project, funded by COST (European Cooperation in Science and Technology).

\section{References}

Awasthi, A.K., Cucchiella, F., D'Adamo, I., Li, J., Rosa, P., Terzi, S., Wei, G., Zeng, X., 2018. Modelling the correlations of e-waste quantity with economic increase. Science of The Total Environment 613, 46-53.

Bartelings, H., van Beukering, P., Kuik, O., Linderhof, V., Oosterhuis, F., Brander, L., Wagtendonk, A., 2005. Effectiveness of landfill taxation. The Netherlands.

Brown, D.P., 2015. Garbage: How population, landmass, and development interact with culture in the production of waste. Resources, Conservation and Recycling 98, 41-54.

Calvo, N., Varela-Candamio, L., Novo-Corti, I., 2014. A dynamic model for construction and demolition (C\&D) waste management in Spain: Driving policies based on economic incentives and tax penalties. Sustainability 6(1), 416-435.

CEWEP, 2017. Landfill tax and bans for EU Member States. http://www.cewep.eu/wpcontent/uploads/2017/12/Landfill-taxes-and-bans-overview.pdf. (Accessed January 2018).

Daniela, R., Mária, B., Lucia, J., 2016. Analysis of the construction industry in the Slovak Republic by bankruptcy model. Procedia-Social and Behavioral Sciences 230, 298-306.

Deloitte, 2015a. Construction and Demolition Waste Management in Poland.

Deloitte, 2015b. Screening template for Construction and Demolition Waste management in The Netherlands.

Deloitte, 2016. Workshop "Improving management of construction and demolition waste". Background paper within the framework of the project "Resource efficient use of mixed waste' European Commission Brussels.

Deloitte, 2017. Resource efficient use of mixed waste. Improving management of construction and demolition waste. European Commission Brussels.

Ding, T., Xiao, J., 2014. Estimation of building-related construction and demolition waste in Shanghai. Waste Management 34(11), 2327-2334. 
EEA, 2016. Environmental taxation and EU environmental policies, Office of the European Union. European Environment Agency, Luxembourg.

Environmental Protection Agency, 2018. Advancing sustainable materials management: 2015 Figures and tables.

Ettlinger, S., Bapasola, A., 2016. Landfill Tax, Incineration Tax and Landfill Ban in Austria. Eunomia and the Institute for European Environmental Policy for the DG Environment of the European Commission.

EUR-Lex, 2017. National transposition measures communicated by the Member States concerning: Directive 2008/98/EC of the European Parliament and of the Council of 19 November 2008 on waste and repealing certain Directives (Text with EEA relevance). http://eur-lex.europa.eu/legal-content/EN/NIM/?uri=CELEX:32008L0098.

(Accessed

December 2017).

European Commission, 2010. Commission regulation of 27 September 2010, amending Regulation (EC) No 2150/2002 of the European Parliament and of the Council on waste statistics. Official Journal of the European Union.

European Commission, 2015. Closing the loop-An EU action plan for the Circular Economy. Communication from the Commission to the European Parliament, the Council, the European Economic and Social Committee and the Committee of the Regions COM 614(2), 2015.

European Commission, 2016. Guidance on the interpretation of the term backfilling https://ec.europa.eu/eurostat/documents/342366/4953052/Guidance-on-

Backfilling.pdf/c18d330c-97f2-4f8c-badd-ba446491b47e. (Accessed July 2019).

European Parliament, 2002. Regulation (EC) No 2150/2002 of the European Parliament and of the Council of 25 November 2002 on Waste Statistics.

European Parliament, 2008. Directive 2008/98/CE of the European Parliament and of the council of 19 November 2008 on waste and repealing cerain Directives. Official Journal of the European Union, pp. 3-30.

Eurostat, 2018. Eurostat statistics for waste flow generation 2016. European Commision. http://epp.eurostat.ec.europa.eu/portal/page/portal/eurostat/homel. (Accessed June 2018).

Fatta, D., Papadopoulos, A., Avramikos, E., Sgourou, E., Moustakas, K., Kourmoussis, F., Mentzis, A., Loizidou, M., 2003. Generation and management of construction and demolition waste in Greece - an existing challenge. Resources, Conservation and Recycling 40(1), 81-91.

Fischer, C., Lehner, M., McKinnon, L.L., 2012. Overview of the use of landfill taxes in Europe. ETC/SCP working paper 1/2012 European Topic Centre on Sustainable Consumption and Production. 
Gálvez-Martos, J.-L., Styles, D., Schoenberger, H., Zeschmar-Lahl, B., 2018. Construction and demolition waste best management practice in Europe. Resources, Conservation and Recycling 136, 166-178.

Gangolells, M., Casals, M., Forcada, N., Macarulla, M., 2014. Analysis of the implementation of effective waste management practices in construction projects and sites. Resources, Conservation and Recycling 93, 99-111.

Justice and Environment, 2012. Implementation of the Waste Framework Directive in the EU Member States. European Network of Environmental Law Organizations, Brno.

Lu, W., Webster, C., Peng, Y., Chen, X., Zhang, X., 2017. Estimating and calibrating the amount of building-related construction and demolition waste in urban China. International Journal of Construction Management 17(1), 13-24.

Llatas, C., 2011. A model for quantifying construction waste in projects according to the European waste list. Waste Management 31(6), 1261-1276

Mália, M., de Brito, J., Pinheiro, M.D., Bravo, M., 2013. Construction and demolition waste indicators. Waste Management \& Research 31(3), 241-255

Marinheiro, L., Russo, M., 2014. Municipal Solid Waste Management in Portugal. An Overview, ISWA Meeting -Working Group on Landfill. Munich, Germany.

Menegaki, M., Damigos, D., 2018. A review on current situation and challenges of construction and demolition waste management. Current Opinion in Green and Sustainable Chemistry.

Monier, V., Mudgal, S., Hestin, M., Trarieux, M., Mimid, S., 2011. Service Contract on Management of Construction and Demolition Waste- Final Report Task 2. A project under the Framework contract

ENV.G.4/FRA/2008/0112. European Commission DG ENV, Brussels.

Namlis, K.-G., Komilis, D., 2019. Influence of four socioeconomic indices and the impact of economic crisis on solid waste generation in Europe. Waste Management 89, 190-200.

Oosterhuis, F.H., Bartelings, H., Linderhof, V.G., van Beukering, P.J., 2009. Economic instruments and waste policies in the Netherlands-Inventory and options for extended use. Institute for Environmental Studies

Oyedele, L.O., Ajayi, S.O., Kadiri, K.O., 2014. Use of recycled products in UK construction industry: An empirical investigation into critical impediments and strategies for improvement. Resources, Conservation and Recycling 93, 23-31.

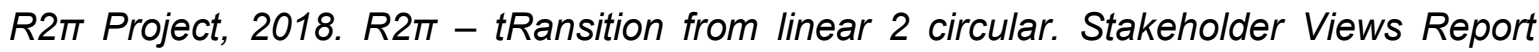
Enablers and Barriers to a Circular Economy. 
RE4 project, 2017. D1.2 deliverable "Statistics Assessment" of the EU funded project titled "REuse and REcycling of CDW materials and structures in energy efficient pREfabricated elements for building REfurbishment

and construction".

Santos, M.T., Lamego, P., Frade, P., 2017. Management options for construction and demolition wastes from residential recuperation. Waste and Biomass Valorization 8(5), 1679-1687.

Silva, R., De Brito, J., Dhir, R., 2014. Properties and composition of recycled aggregates from construction and demolition waste suitable for concrete production. Construction and Building Materials 65, 201-217.

Taffese, W.Z., 2018. Suitability investigation of recycled concrete aggregates for concrete production: an experimental case study. Advances in Civil Engineering 2018.

Tam, V.W.-Y., Lu, W., 2016. Construction waste management profiles, practices, and performance: a cross-jurisdictional analysis in four countries. Sustainability 8(2), 190.

Tingley, D.D., Cooper, S., Cullen, J., 2017. Understanding and overcoming the barriers to structural steel reuse, a UK perspective. Journal of Cleaner Production 148, 642-652.

Vieira, C.S., Pereira, P.M., 2015. Use of recycled construction and demolition materials in geotechnical applications: A review. Resources, Conservation and Recycling 103, 192204.

Wahlström, M., zu Castell-Rüdenhausen, M., Hradil, P., Hauge-Smith, K., Oberender, A., Ahlm, M., Götbring, J., Hansen, J.B., 2019. Improving quality of construction \& demolition waste: Requirements for pre-demolition audit. Nordic Council of Ministers.

Younes, M.K., Nopiah, Z., Basri, N.A., Basri, H., Abushammala, M.F., Maulud, K.N.A., 2015. Prediction of municipal solid waste generation using nonlinear autoregressive network. Environmental monitoring and assessment 187(12), 753. 


\section{Highlights}

- Waste Framework Directive (WFD) set a recycling target to attain $70 \% \mathrm{CDW}$ recycling by 2020 .

- Multi-faceted analysis of CDW waste generation and recovery practice in Europe.

- Cross-EU Member States' analysis of CDW generation correlation to construction turnover, GDP and capita.

- Eleven MS still need to improve their recovery performance.

- No correlation was found between taxations and CDW landfilled or recovered. 